\title{
КАТЕГОРІї ЧАСУ ТА ПРОСТОРУ В ІНФОРМАЦЙНИХ ПРИРОДНО-МОВНИХ ТЕХНОЛОГІЯХ
}

\begin{abstract}
Анотація: В роботі аналізуються мовні засоби відтворення просторових та часових відношень для потреб автоматичного опрацювання мовного матеріалу. Акцентується увага на структурній організації цих засобів, які багато в чому подібні між собою.

Ключові слова: мовного матеріалу, природно-мовні технології, індивідуальною мовною системою, базою знань.
\end{abstract}

\section{Вступ}

Мовленнева діяльність актуалізуеться індивідуальною мовною системою (IMC) конкретної людини - отже, всі сучасні інформаційні природномовні технології (IПМТ), що намагаються моделювати окремі прояви багатогранної мовленнєвої діяльності, повинні спиратися на модель IMC, яка (як відомо за Л.В.Щербою [1]) визначається двома складовими: знаннями про мовну організацію (на свідомому чи підсвідомому рівнях) - лінгвістичним процесором (ЛП) та накопиченим досвідом про середовище свого існування - нашою базою знань (БЗ), де формуеться модель світу, в якому ми живемо. Без моделювання IMC з урахуванням обох складових - ЛП та БЗ - всі наші спроби розбудови моделей, адекватних у певному сенсі особливостям мовленнєвої діяльності людини, приречені на невдачу.

В роботі автора [2] послідовно формувалось нове бачення організації мови, яке виводить нас на системний рівень мовної організації, що дозволяе вже тепер досить кваліфріковано ставити питання щодо створення програмного продукту ЛП. Наріжним каменем системної організації постає формально визначене поняття базової семантико-синтаксичної структури (БССС), витоки якої, багато в чому, визначаються структурнофункціональним рівнем нейроорганізації зорового тракту людини [3] та зумовлюють структурні особливості мови взагалі. Базова структура за визначенням - це вербалізована форма відтворення довільної ситуації реального або віртуального світу (дивись [2]), що існуе у триедності часу, простору та дії. Отже, координати часу та простору - це необхідні компоненти БССС, тому їх структурна організація постає однією з найважливіших проблем на шляху створення ЛП для автоматичного опрацювання природно-мовної інформації.

\section{Платформа дослідження}

Категорії часу та простору настільки важливі атрибути нашого буття, що для розуміння їх використання бажано звернутися до кваліфікованих джерел. Звернімося, наприклад, до фрізичної енциклопедії, де

(c) Ю.І. Кисленко, О.С. Черевко, 2011 
подаються найбільш узагальненні їх визначення та аналізуються їх особливості. "Простір та час у фізиці визначаються у загальному вигляді як фундаментальні структури координації матеріальних об’ектів та їх станів: система відношень, що визначає координацію співіснуючих об'єктів (відстань, оріентація тощо) формують простір, а система відношень, що відтворює координацію змінюючих один одного станів чи явищ (послідовність, протяжність тощо) формують час. Простір та час постають організуючими структурами різних рівнів фрізичного пізнання і відіграють важливу роль у міжрівневій взаємодії” [4].

Таке визначення сучасної платформи класичної фізики стосовно головних атрибутів нашого існування постає конструктивним підгрунтям інтуїтивних поглядів гуманітарної спільноти (психологів, фрілософрів, лінгвістів), що наше довкілля існуе в триедності часу, простору та дії. Коли ж головна функція мови визначається як адекватне відтворення довкілля, то на перший план, природно, виступають питання аналізу мовних засобів для відтворення просторових та часових відношень і фрiксації послідовності їх станів або змін. Отже, нас цікавитимуть, в першу чергу, мовні засоби та їх організація для відтворення різноманітних просторово-часових (П/Ч) відношень з метою подальшого їх використання для автоматичного опрацювання інформації в сучасних інформаційних природно-мовних технологіях.

Існуе досить широкий пласт літератури подібного кшталту, де з різних позицій (філософських, лінгвістичних, кібернетичних) розглядаються питання відтворення просторових та часових відношень у мовному матеріалі. Увага до цієї проблеми набула особливої гостроти з початком формування інформаційних технологій, оріентованих на опрацювання природно-мовної (ПМ) інформації. Звісно, не можна не згадати в цьому контексті роботи, що пов'язані зі спробами моделювання мовленневої діяльності. Одна з перших спроб була здійснена під керівництвом Д.О. Поспелова, що презентована роботою [5]. Слід підкреслити намагання авторів проаналізувати та подати узагальнену модель часу та простору як визначальних атрибутів нашого існування з метою подальшого їх використання в програмних продуктах. В роботі підкреслені такі властивості цих категорій як: ненаправленість простору, однонаправленість часу, безперервність часу та простору, нескінченність часу та простору, гомогенність простору тощо. Вказано також, що залежно від потреб розрізняють системи відтворення відношень: абсолютні, відносні, розмиті. Проте невідомо, наскільки ефективно авторам вдалося перекласти на плечі комп'ютера цю віртуальну модель.

Інша спроба використання просторових відношень досить вузької сфрери презентована була роботою автора [2], де на програмному рівні були реалізовані процедури синтезу та аналізу просторових відношень. На особливу увагу заслуговуе запропонована графічна інтерпретація Пвідношень (образотворчі засоби семантики - за Ю.Д. Апресяном [6]), що дозволило побудувати систему, яка працюе зі “смислом" окремих просторових термінів і за текстом синтезуе П-відношення (режим аналізу пові- 
домлення) або, навпаки, за графічним поданням просторових відношень визначає його мовну інтерпретацію (режим синтезу повідомлення).

Звісно, є ще багато інших досліджень часу та простору як важливих категорій нашого існування, що зачіпають інші аспекти їх актуалізації на мовному рівні, проте нас цікавитимуть більше структурні особливості відтворення часу та простору у мовному матеріалі. Фахово проблемами часу та простору (абсолютного часу та абсолютного простору) цікавляться фізики та математики, нас же більше цікавитимуть різні схеми відтворення П/Ч-відношень на мовному рівні. У загальному випадку, коли наш життевий простір заповнений множиною об'єктів/суб'єктів, різних станів та ситуацій, існуе і нескінченна кількість просторово-часових відношень; проте, важливо підкреслити, що, практично, кожна мова має засоби відтворення найтонших і найрізноманітніших П/Ч-відношень, і наша мета - простежити хоча б основні схеми та структури формування таких відношень.

\section{Одиниці виміру та їх особливості}

Якщо головна функція мови - адекватне відтворення навколишнього середовища, що існуе в триєдності часу, простору та дії, то, зазвичай, продуктивним постає аналіз співвідношення “Дійсність-Текст"; наше завдання - проаналізувати особливості організації мовних засобів для адекватного відтворення просторово-часових відношень. Звісно, треба враховувати, що категорії існування світу - час та простір - це категорії безперервні, тоді як мовні засоби мають суто дискретну природу. Отже, можемо вважати, що наш життевий простір е тривимірним (просторові координати $X, Y, Z$ ), а час вважатимемо четвертою координатою $T$. Мабуть, промовчимо стосовно початку відліку часу та простору, відсилаючи їх до моменту створення всесвіту.

Тут доречно ще раз звернутися за допомогою до фахівців - фізиків [4]: “Абсолютний, істинний, математичний час сам по собі і за своєю суттю, без будь-якого відношення до будь-чого зовнішнього, протікає рівномірно і інакше називається тривалістю. Абсолютний простір за самою своєю суттю безвідносно до будь-чого зовнішнього залишається завжди однаковим та нерухомим". Тож, практично, при аналізі часових та просторових відношень йдеться про фіксацію або поточних П/Ч координат існування окремої складової довкілля, або відстані між об'єктами/суб'єктами, подіями, ситуаціями тощо. Всі одиниці виміру часу та простору умовно можемо віднести до одиниць кількісних та якісних; сфера використання перших - це технічні напрями застосування, математичні та теоретичні розробки тощо, тоді як інші - частіше використовуються для відтворення просторово-часових відношень на побутовому рівні. Кількісні одиниці визначаються чіткою логікою організації та певними сферами використання, тоді як якісні - частіше відносяться до нечітких множин, де не зовсім однозначно окреслені межі їх застосування, а семантичне навантаження визначається конкретною ситуацією. Приклади використання одиниць виміру різних рівнів наведені у Табл.1. Слід тільки зазначити, 
що коли наш простір визначається як тривимірний $(3 D-$ за сучасними уподобаннями), то і одиниці виміру також повинні відповідати його особливостям, тобто, бути одновимірними, двовимірними та тривимірними.

Важливо тут підкреслити суттеву різницю між кількісними та якісними одиницями виміру: кількісні одиниці, вкладаючись одна в одну, дозволяють відтворити весь континуат (безперервність та нескінченність) категорій часу та простору, тоді як якісні одиниці фіксують лише окремі їх проміжки, що пов'язані з певними якісними оцінками, ситуаціями, подіями, важливими для існування людини та їі життедіяльності.

Система CI подае нам вихідні одиниці часу “секунда" та простору “метр” і вказуе алгоритм формування всіх похідних одиниць.

Таблиця 1

Одиниці виміру часу та простору

\begin{tabular}{|c|c|c|c|}
\hline \multicolumn{2}{|r|}{ Кількісні одиниці } & \multicolumn{2}{|c|}{ Якісні одиниці } \\
\hline \multirow[t]{3}{*}{ שָ } & \multirow{3}{*}{$\begin{array}{l}\text { секунда, хвили- } \\
\text { на, } \\
\text { година, доба, ти- } \\
\text { ждень, місяць, } \\
\text { декада, квартал, } \\
\text { рік, десятиріччя }\end{array}$} & $\begin{array}{l}\text { день, ніч, ранок, ве- } \\
\text { чір, північ }\end{array}$ & час доби \\
\hline & & $\begin{array}{l}\text { сніданок, обід, ланч, } \\
\text { вечеря }\end{array}$ & час прииому їжі \\
\hline & & $\begin{array}{l}\text { понеділок, вівторок, } \\
\text { середа, четвер, п'я- } \\
\text { тниця, субота, неділя }\end{array}$ & $\begin{array}{l}\text { послідовний } \\
\text { порядок днів у тижня }\end{array}$ \\
\hline 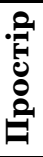 & $\begin{array}{l}\text { метр, кілометр, } \\
\text { сантиметр } \\
\text { міліметр }\end{array}$ & лікоть, сажень, крок & міри довжин \\
\hline
\end{tabular}

Система СI подає нам вихідні одиниці часу “секунда" та простору “метр” і вказуе алгоритм формування всіх похідних одиниць. Якщо нас цікавлять, в першу чергу, мовні засоби відтворення просторово-часових відношень, то не завадило б враховувати можливість ідентифрікації всіх одиниць, які визначаються стандартною системою префіксів (див. Табл.2), які додаються до базових, формуючи весь спектр похідних одиниць, що можуть використовуватися в мовній інформації [7].

Слід підкреслити ще одну особливість використання одиниць виміру, що пов'язана саме з мовними особливостями їх використання. Поперше, ідентифікація окремих проміжків часу та простору у загальному випадку відбувається шляхом використання певної множини різномасштабних одиниць (“12 годин”, “15 діб”, “5 км” тощо); по-друге, система відтворення П/Ч відношень формуеться таким чином, щоб послідовність одиниць була здатною з певною точністю презентувати довільний проміжок (“12 год. 18 хв.”, “5 км. 200м.” тощо); по-трете, важливим елементом використання кількісних та якісних одиниць виміру є можливість урахування порядку використання однотипних одиниць виміру при іден- 
Префікси системи СI для формування похідних одиниць

\begin{tabular}{|c|c|c|c|c|}
\hline \multirow{2}{*}{$\begin{array}{l}\text { Назва } \\
\text { пpe- } \\
\text { diкca }\end{array}$} & \multicolumn{2}{|c|}{$\begin{array}{l}\text { Позначення } \\
\text { префрікса }\end{array}$} & \multirow[t]{2}{*}{ Множник } & \multirow[t]{2}{*}{$\begin{array}{c}\text { Назва } \\
\text { множника }\end{array}$} \\
\hline & \begin{tabular}{l|} 
Україн \\
ське
\end{tabular} & \begin{tabular}{|l|} 
Міжна \\
родне
\end{tabular} & & \\
\hline екса & $\mathrm{E}$ & $\mathrm{E}$ & $10^{18}$ & Квінтиліон \\
\hline пета & $\Pi$ & $\mathrm{P}$ & $10^{15}$ & Квадриліон \\
\hline тетра & $\mathrm{T}$ & $\mathrm{T}$ & $100000000000=10^{12}$ & Трильйон \\
\hline гіга & $\Gamma$ & $\mathrm{G}$ & $100000000=10^{9}$ & Мільярд \\
\hline мега & $\mathrm{M}$ & $\mathrm{M}$ & $1000000=10^{6}$ & Мільйон \\
\hline кіло & $\mathrm{K}$ & $\mathrm{K}$ & $1000=10^{3}$ & Тисяча \\
\hline гекто & $\Gamma$ & $\mathrm{h}$ & $100=10^{2}$ & Сто \\
\hline дека & да & da & $10=10^{1}$ & Десять \\
\hline деци & Д & $\mathrm{d}$ & $0.1=10^{-1}$ & одна десята \\
\hline санти & c & $\mathrm{c}$ & $0.01=10^{-2}$ & одна сота \\
\hline мілі & $\mathbf{M}$ & $\mathrm{m}$ & $0.001=10^{-3}$ & одна тисячна \\
\hline мікро & MK & $\mathrm{mc}$ & $0.000001=10^{-6}$ & одна мільйонна \\
\hline нано & $\mathrm{H}$ & $\mathrm{n}$ & $0.000000001=10^{-9}$ & одна мільярдна \\
\hline піко & $\Pi$ & $p$ & $0.000000000001=10^{-12}$ & одна трильйонна \\
\hline форемто & dp & $\mathrm{f}$ & $10^{-15}$ & одна квадроліонна \\
\hline отTо & $\mathrm{a}$ & $a$ & $10^{-18}$ & одна квінтиліонна \\
\hline
\end{tabular}

тифрікації проміжків часу та простору (що притаманно, до речі, багатьом системам відліку).

Ця властивість дозволяє додатково визначати не лише відстань, а й враховувати порядок використання окремих одиниць на певному відрізку, коли позиція одиниці виміру пов'язана з певними особливостями відтворюваної ситуації (“на 20-му кілометрі траси....”, “о 18-й годині....”, “на 5-й хвилині. ..” тощо). Важливо тут підкреслити семантичну розбіжність у використанні кількісних та порядкових оцінок відліку. Кількісний характер використання одиниць виміру називає лише множину одиниць певного кшталту, враховуючи їх кінцеві оцінки. Так термін “5 кілометрів” означає всю відстань від умовного початку відліку до кінцевої позначки кількісної оцінки. Термін же “5-й кілометр" визначає відстань лише однієї одиниці виміру, починаючи від кінця четвертого до початку шостого. Слід зауважити, що ця дихотомія “кількість/порядок” використовується досить ефективно в мовній практиці для ідентифікації не лише просторово-часових залежностей, а й окремих складових множини об'єктів/суб'єктів із загальної їх кількості, акцентуючи увагу читача саме на конкретному об'єктові серед йому подібних. Ввівши систему одиниць часу та простору, можемо вже перейти до аналізу різних схем формування П/Ч-відношень. Але спочатку розгля- 
немо варіанти реалізації П/Ч-відношень, що не використовують одиниць виміру.

\section{Фіксація поточних координат часу та простору}

Перший варіант формування просторово-часових відношень на шляху філогенезу мови був пов'язаний, мабуть, зі спробою актуалізації цих відношень без урахування будь-яких одиниць виміру (не знала ще первісна людина як вимірювати час та простір!). Аналогічна ситуація спостерігається в онтогенезі мови на етапах опанування дитиною категорій часу та простору (дивись Гвоздева А.Н. [8]). Час та простір визначаються прислівниками “mym”, “maл”, “ось”, “mеnер”, що визначають, власне, поточні координати мовця (див. Табл.3). Термін “ось” навіть важко з впевненістю віднести до часової чи просторової оцінки. Трохи пізніше вже фріксуються П/Ч-відношення в більш конкретній формі: “на цьолу лісиі”, “в певний лиолент иасу” тощо. Наступний етап пов'язаний вже з формуванням та використанням одиниць виміру, мабуть, спочатку якісних і лише значно пізніше - кількісних, які вже дозволяють виокремлювати певні відстані у часі та просторі. Для аналізу структури категорій з використанням вже одиниць виміру введемо певну нотацію.

Поточні координати часу та простору

Таблиця 3

\begin{tabular}{|c|c|c|c|}
\hline \multicolumn{2}{|r|}{ Минулий час } & Теперішній час & Майбутній час \\
\hline \multirow{6}{*}{ శ్ } & попередньої миті & тепер & наступної миті \\
\hline & Вчора & цієї миті & Завтра \\
\hline & Минулого тижня & сьогодні & наступного тижня \\
\hline & минулого року & Цього тижня & наступного місяця \\
\hline & минулої декади & цього року & наступного кварталу \\
\hline & минулого століття & цього ранку & наступного півріччя \\
\hline \multirow{4}{*}{ 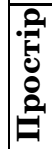 } & \multicolumn{3}{|c|}{ Простір абсолютний (одновилгірний) } \\
\hline & & на цьому місці & \\
\hline & & на тому місці & \\
\hline & & безвідносно subj/obj & \\
\hline
\end{tabular}

\section{Нотація формування просторово-часових відношень}

Для аналізу структури П/Ч-відношень введемо відповідні позначення: часову відстань (відрізок часової осі) позначатимемо через $T$, просторову відстань подамо через $S$, тоді, відповідно, кількісні одиниці виміру часу приймаємо за $t_{i}$, а кількісні одиниці виміру простору - як $s_{i}$, кількість одиниць виміру певного кшталту позначимо - $n$.

\section{Визначення відрізків часу та простору}

Узагальнена процедура визначення відстані у часі та просторі добре відома і виглядатиме наступним чином:

$$
S=n_{1} * s_{1}+n_{2} * s_{2}+\ldots+n_{k} * s_{k}=\sum n_{i} * s_{i}
$$


"8 метрів 5 сантиметрів 18 міліметрів"

$$
T=n_{1} * t_{1}+n_{2} * t_{2}+\ldots+n_{k} * t_{k}=\sum n_{i} * t_{i}
$$

“2 години 45 хвилин 30 секунд”.

До цього часу ми працювали з кількісними вимірами простору та часу, що визначають певні відрізки цих категорій. Проте там, де існуе "Кількість” завжди присутня й інша категорія "Порядок". Особливість використання цієї категорії - у виокремленні із певної множини однакових одиниць конкретної міри (просторової чи часової) з урахуванням їі протяжності від початку до закінчення або до поточного моменту (моменту мовлення). Приклади можуть бути наведені досить широко:

“останній тиждень лісяця", “сілнадиятий кілолетр",

“1997 рік”, “двадиять перше сторічия”.

Кількісна оцінка завжди фіксуе наявність кінцевої межі виміру, звернення ж до порядкової форми передбачає актуалізацію всього визначеного проміжку.

\section{Відносні схеми формування просторово-часових відношень}

До цього часу ми аналізували паралельно мовні засоби відтворення часових та просторових відношень як одновимірних характеристик, не акцентуючи увагу на системах відліку цих відстаней. Незважаючи на попереднє зауваження стосовно початку відліку світових координат часу та простору, які сприймаємо як невизначені, відлік часу та простору ведеться відносно визначальних координат нашого існування: просторові координати - це наш дім-Земля, а часові - це простір існування людства, зафіксований в календарних системах. Тут не зачіпаємо такі категорії як “абсолютний час" та “абсолютний простір", які відіграють суттеву роль у формуванні теорії становлення світу та теоретичних розробок, а на побутовому рівні майже не використовуються. Значно важливішими у житті постають відносні системи відліку часу та простору, коли за початок координат приймається окремий об'єкт/суб'єкт (для формування П-відношень) або конкретна подія/ситуація (для ідентифікації Ч-відношень).

У роботі автора [3] свого часу досліджувалися особливості формування Ч-відношень за відносною системою. Було показано, що коли одна подія (ситуація) зміщуеться відносно іншої, то мовна практика опрацювала відповідні засоби для досить тонкої ідентифікації подібних відношень. Приблизний підрахунок подібних Ч-відношень складав близько шестисот типів. Аналогічним чином, враховуючи структурний рівень формування обставин простору, можемо проаналізувати можливість формування П-відношень за відносною системою, коли відлік відстані ведеться відносно конкретного об'єкта/суб'єкта, просторові координати якого нам добре відомі або з контексту, або з нашого досвіду. Можливі варіанти формування П/Ч-відношень представлені рисунками 1 та 2 ; при їх зіставленні чітко простежуеться структурна одноманітність організації П/Ч-відношень 
відносно початку відліку. До того ж слід нагадати тезу, що кожна мова має відповідні засоби для відтворення (фіксації) найрізноманітніших П/Ч-відношень нашого існування.

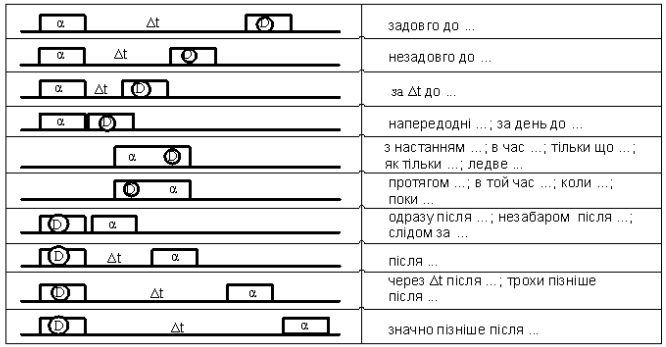

Рис. 1 - Часові співвідношення двох подій: $\alpha$ - відтворювана подія середовища, $D$ - довільна подія (момент віднесення), $\Delta t$ - відстань між $\alpha$ і $D$, що визначається на континуаті часової осі, $t_{b}$ - часова вісь.

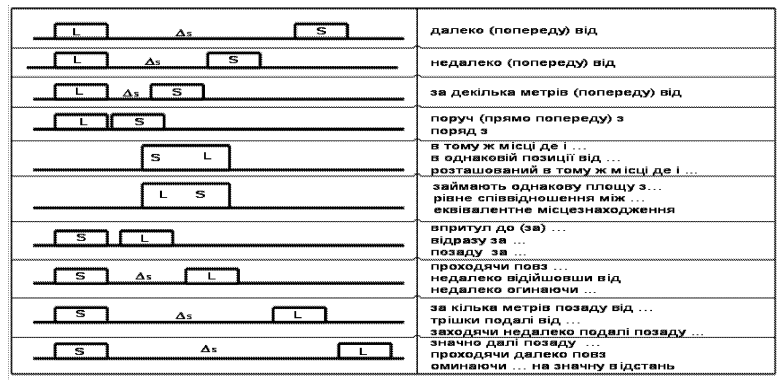

Рис. 2 - Просторові співвідношення двох об'єктів: $L$ - об'єкт, що співвідноситься, $S$ - довільний об'єкт, відносно якого здійснюеться відлік (точка віднесення), $\Delta s$ - відстань між $L$ і $S$, що визначається на континуаті просторової осі, $s_{b}$ - просторова вісь.

\section{Визначення відстані між двома об'ектами, подіями}

Вище розглядалися системи відліку П/Ч-відношень відносно однієї подіі//ситуації чи конкретного об'єкта/суб'єкта. Проте у одновимірному варіанті можлива також фіксація відстані між двома об'єктами, подіями тощо. У такому випадку, у повідомленні присутня актуалізація обох елементів, стосовно яких формуеться просторове чи часове відношення. Наприклад, для фіксації П-відношень матимемо: "Між човнол та островол відстань вже складала не більше сотні летрів"; а для часових відношень, відповідно - "Між заручинали і весілляли пролиайнуло вже кілька лісяиів". 


\section{Висновки}

В роботі ретельно проаналізовано співвідношення “Дійсність-Текст" в плані аналізу мовних засобів відтворення найважливіших категорій існування нашого світу - часу та простору. Дослідження присвячене аналізу структурного рівня організації мовних засобів, де головними складовими виступають: одиниці виміру (кількісні та порядкові), їх параметри, а також використовуються службові елементи мови для відтворення П/Ч-відношень окремих складових нашого оточення. В роботі представлені кількісні та якісні одиниці виміру часу та простору, проаналізовані механізмами фіксації поточних координат моменту мовлення, враховані особливості використання абсолютних та відносних систем відліку. Bсі ці питання проаналізовані в площинах 1D, що зумовлюе відповідні формати подання П/Ч-відношень.

\section{Література}

1. Щерба Л.В. О трояком аспекте языковых явлений и эксперименте в языкознании : избр. труды. /Щерба Л.В. Языковая система и речевая деятельность. - Л.: Наука, 1974. - 24-39 с.

2. Кисленко Ю.І. Архітектура мови (Лінгвістичне забезпечення інтелектуальних інтегрованих систем). - учбовий посібник. - К.: Вiпол, 1998. - $344 \mathrm{c}$.

3. Кисленко Ю.И. От мысли к знанию (нейрофизиологические основания): Монография. - К.: “Український літопис",2008.-101 с.

4. Физическая энциклопедия (под ред. А.М. Прохорова) Т.4. - М.:1994. $-704 \mathrm{c}$.

5. Кандрашина Е.Ю., Литвинцева Л.В., Поспелов Д.А. Представление знаний о времени и пространстве в интеллектуальных системах. М.: Наука, 1989. - 328 с.

6. Апресян Ю.Д. Лексическая семантика. - М.: Наука, 1974. - 307 с.

7. Енохович А.С. Справочник по физике и технике. Учебное пособие для учащихся. - М.: Просвещение, 1989. - 224 с.

8. Гвоздев А.Н. Формирование у ребенка грамматического строя русского языка. - М.: АПН, 1949. - 268 с.

Отримано 11.03.2011 p. 